REVIEW ARTICLE

\title{
Keratosis Obturans Management
}

\section{Achmad Chusnu Romdhoni ${ }^{1 *}$}

${ }^{1}$ Department of Otorhinolaryngology-Head and Nech Surgery, Faculty of Medicine, Universitas Airlangga - Dr. Soetomo General Hospital Surabaya, Indonesia

\author{
A R T I C L E I N F O \\ Article history: \\ Received 2 May 2018 \\ Received in revised form 23 May \\ 2018 \\ Accepted 29 May 2018 \\ Available online 30 April 2018

\section{Keywords:} \\ Keratosis obturans, \\ Desquamation keratin layer, \\ Meatus acoustic exsternus. \\ *) Corresponding author: \\ romdhoni-a-c@fk.unair.ac.id
}

\begin{abstract}
A B S T R A C T
Keratosis obturans is a large accumulation of plaque from desquamated keratin distributed in the ear. The etiology of keratosis obturans remains unclear. Keratosis obturans generally occurs in young patients between the ages of 5-20 years and can attack one or both ears. Patients suffering from keratosis obturans and have a history of bronchiectasis or sinusitis reported $77 \%$ of adolescent cases, only $20 \%$ of adult cases. The diagnosis of keratosis obturance is made on the basis of anamnesis and clinical examination, while CT scan is performed to determine whether or not bone erosion is present. This disease can be controlled by performing clearance of the ear canal periodically every one to three months to reduce debris accumulation. Ear dropping of mixtures of alcohol or glycerin in $3 \%$ peroxide, three times a week can often be helpful.
\end{abstract}

\section{Introduction}

Keratosis obturans is a buildup of desquamation of the epidermal layers of keratin on the external acoustic meatus (MAE), pearly white in color, it can form clots and cause full sense and hearing loss. This disease is not about MAE cartilage, typically this lesion is confined to MAE, without causing bone decomposition. The tympanic membrane looks normal, but usually looks thick or retraction $(1,2)$.

In 1850 Toynbee first discovered the early symptoms of keratosis obturans described as MAE cholesteatoma. The term keratosis obturans was introduced by Wreden in 1874 to distinguish it from impacted cerumen. Since then 150 cases of keratosis have been reported and only 15 cases of MAE cholesteatoma have been reported (3-5).

Keratosis obturans is a rare disease, whereas frequency of MAE cholesteatoma is estimated to be equal to 1000 new otological cases and each case there are four or five cases of keratosis obturans. Keratosis obturans often occurs at a young age (6).

Etiology of keratos obturans is unknown, although it can be caused by chronic hyperemia that increases desquamation of keratin and epidermal debris formation. Other theories may be caused by eczema, seborrhoeic dermatitis, furunculosis and abnormal epithelial migration sometimes even in association with chronic bronchiectasis and sinusitis. Keratosis obturans and MAE cholesteatomas are two clinically distinct clinical conditions and pathologic features $(3,4)$. The treatment of keratosis obturans is by regular MAE cleansing and topical therapy, whereas MAE cholesteatoma generally requires surgical intervention (7). The purpose of this review is to discuss treatment of keratosis obturans..

\section{Keratosis Obturans}

Keratosis obturans is a large accumulation of plaque from keratin desquamation in MAE. Keratosis obturans is a form of dermatitis with marked inflammation and an

Biomolecular and Health Science Journal 
increase in MAE skin vascularization. Chronic inflammation causes increased desquamation of the MAE skin and reduces abnormal epithelial migration. The MAE epithelium and the tympanic membrane are both clearly marked thickening as a result of dermal inflammation. The accumulation of keratin laminar in MAE is the most common form of desquamation, accumulation on the outer edge (figure 1). Piepergerdes and colleagues in 1980 claimed that the keratosis obturans was produced by MAE skin disease whereas MAE cartilage disease was the basis for cholesteatoma in $\operatorname{MAE}(1,3,4)$.

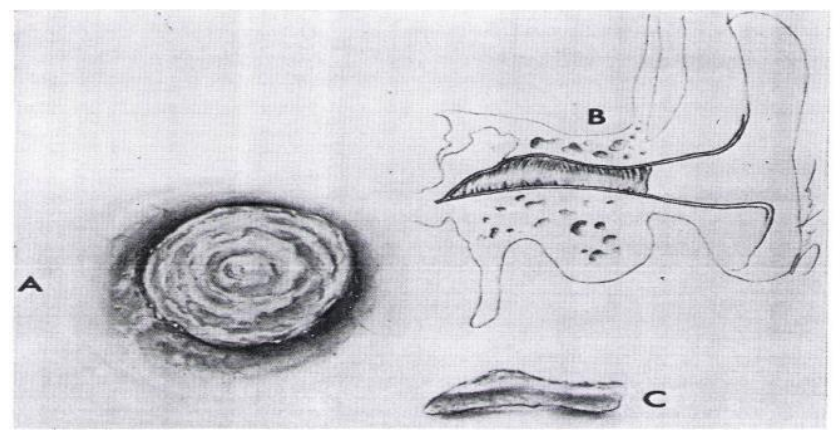

Figure 1. A. The keratin layer covers the MAE. B. Keratinforming plug in the some part of MAE bone and C. Keratin after removal (5).

\section{Incidence}

Keratosis obturans generally occurs in young patients between the ages of 5-20 years and can attack one or both ears. Patients suffering from keratosis obturans and have a history of bronchiectasis or sinusitis reported $77 \%$ were adolescent cases, only $20 \%$ were adult cases. In 1956 Morrison reported $70 \%$ of 50 cases of keratosis obturans among 20 patients aged 5-9 years, 15 patients between the ages of $9-19$ and 15 patients aged between 20-59 years and 44\% occurred bilaterally. In 1958 Black and Clayton reported keratosis obturans in children with a $90 \%$ incidence occurring bilaterally (5).

\section{Etiopathogenesis}

The etiology of keratosis obturans remains unclear. Several hypotheses suggest keratosis obturans associated with eczema, seborrheic dermatitis and furunculosis. The keratosis obturans occurs due to epithelial abnormal migration of the MAE skin layer. Normally, the epithelium from the surface of the tympanic membrane of pars flaccida migrates down to the pars tensa and moves inferiorly across the tympanic membrane, but the movement of epithelial cells in this disease appears reversed. The failure of this migration or the presence of obstruction at the time of migration caused by the keratin layer causes the accumulation of epithelial debris on the inside of the MAE. This is consistent with the study of normal skin on the outer ear made by Alberti in 1964 indicating that there is normally an epithelial migration of the tympanic membrane to MAE $(3,4,5)$.
According to Mayer, Paparella and Shumrick keratosis obturans can be caused by several factors including the excessive production of epithelial cells, the failure of skin epithelial migration and the inability of self-cleaning mechanisms by MAE. Self-cleaning mechanism by MAE is the result of coordination of keratin maturation process and outward cell migration. In keratosis obturans this mechanism do not work. In 1956 Morrison reported the association of bronchiectasis and sinusitis with the occurrence of keratosis obturans the emergence of the main cause hypothesis of bronchiectasis caused by reflex stimulation of the serum gland by the autonomous sympathetic nervous system that causes hyperemia and epidermal clogging, it is not explained why gland stimulus causes the epithelial migratory skin migration errors in MAE (4.5).

\section{Classification}

According to Hawke and Shanker there are two types of keratosis obturans. The first type is a chronic inflammation of subepithelial tissue and this results in epithelial hyperplasia and the formation of squamous material in MAE. The second type there is no chronic inflammation in the skin layer of MAE, occurs bilaterally and possibly because of a hereditary abnormality or the presence of an unknown enzyme that contributes to the separation of the superficial layer of keratin, this condition may occur if the layer moves outward during the process normal migration. 3.7 According to Soucek and Michaels, an abnormal epithelial migration may be derived from the tympanic membrane itself or MAE, thereby causing two different types of diseases. This difference is far from the type that Hawke and Shanker described (3).

\section{Histopathology}

Keratosis obturans histopathologically the thickened of epithelial layer and subepithelial layer exhibit a combination of dilated capillaries and infiltration of chronic inflammatory cells. The squat keratin layer peels off around the MAE. The old layer is pushed to the center and the result is a lamellar (onionskin-layer) composed entirely once by dense squat keratin. Solid leaflets such as leaf and orthokeratotic keratinaceous material and lack of epithelial lining therein (Fig. 2).

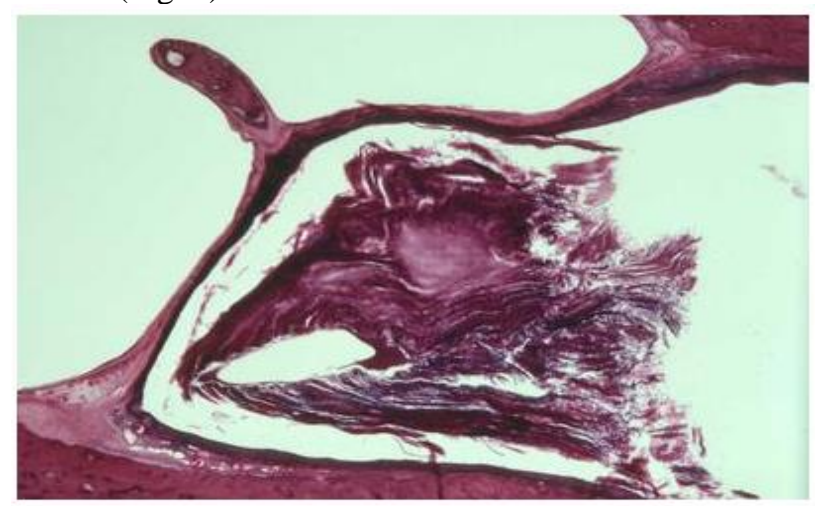


Figure 2. Horizontal slices showing the plug closure on the MAE bone by a collection of squamous keratin (2).

\section{Diagnosis}

\section{Clinical Overview}

Keratosis obturans is generally affected young people, less than 40 years old, bilateral conduction type hearing loss, severe pain, wider MAE and hyperemia, tinnitus, intact but thicker tympanic membrane, rarely found otore $(2,6)$. Hearing loss and severe pain is a secondary complaint that always occurs due to keratin accumulation in MAE. An otoscopic examination was obtained by the accumulation of keratin debris clumps on a white MAE containing a brown serum in the middle (figure 3). The presence of keratin clumps in the MAE increases the pressure on the MAE wall resulting in bone remodeling. This causes bone widening in MAE accompanied by epithelium inflammation, the tympanic membrane thickened but still intact. The Rinne and Weber tests using a $512 \mathrm{~Hz}$ rotation were performed to determine conduction deafness and compared with audiometric examination (1).

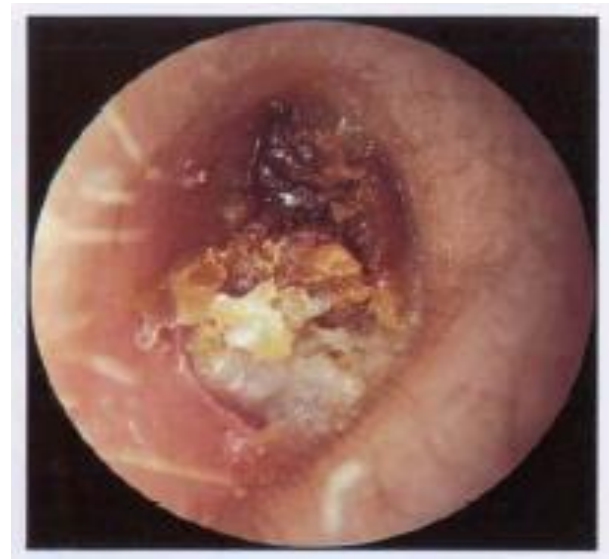

Figure 3. Keratosis obturans. ${ }^{1}$

Radiological features of keratosis obturans with CTScan bone examination showed soft tissue lesion, generally bilateral, located in MAE, extending and dilating MAE resulting in smooth scalloping without the underlying bone erosion (figure 4).The diagnosis of keratosis obturance is made on the basis of anamnesis and clinical examination, while CT scan is performed to determine whether or not bone erosion is present. Anamnesis obtained severe ear pain, hearing loss bilateral conduction type, rare occurrence otore. On otoscopy examination keratin accumulation seen along MAE, tympanic membrane intact but thicker. On support examination of CT scan obtained erosion and widening of MAE. In histopathologic examination, keratin blockage is found, in the keratosis obturans looks like a geometric line inside the MAE that looks like an onionskin layer image. ${ }^{2.9}$

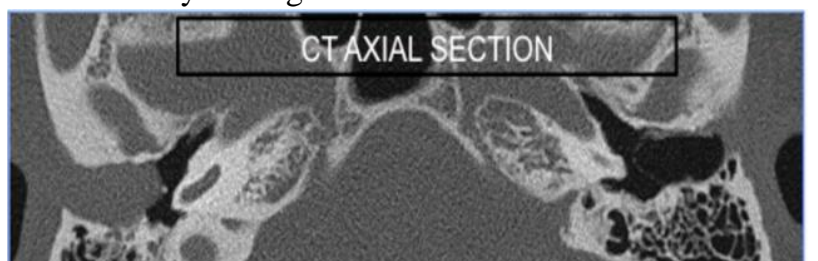

Figure 4. Ct-scan of keratosis obturans. ${ }^{8}$

\section{Differential Diagnosis}

Keratosis obturans needs to be distinguished from MAE cholesteatoma because it has similar clinical features but different treatment. Cholesteatoma is characterized by a lesion formed by a squamous epithelium of berkeratin that occurs in the temporal bone, the inferior and posterior wall bone of MAE is most commonly affected. Treatment of MAE cholesteatoma depends on the severity of the disease. Conservative therapy is performed when cholesteatoma and bone erosion are still limited in MAE. The operative action is performed when there is an extension out of the MAE. ${ }^{4.5}$

There are several things that differentiate keratosis obturans with cholesteatoma. Keratosis obturans occurs in young patients with acute otalgia complaints and bilateral conduction-type hearing loss. MAE cholesteatoma occurs in elderly, generally unilateral, and clinical symptoms are characterized by dull pain in the ears and presence of otore. Hearing is usually still within normal limits. The ear examination of the keratosis obturans patient obtained MAE is fully loaded with keratin plaque, the MAE appears widened and hyperemia. In MAE cholesteatoma, an epidermal diverticulum derived from the lower wall of the MAE, while other parts of the unaffected MAE appears normal. There is no bone erosion in keratosis obturans, whereas in MAE cholesteatoma there is bone erosion. ${ }^{10.11}$

\footnotetext{
Management

Treatment of keratosis obturans in the form of removal of desquamated squamous epithelium. In addition, surgery may be performed with general anesthesia for debridement. This disease can usually be controlled by regular MAE cleansing every one to three months to reduce debris accumulation. Ear dropping of mixtures of alcohol or glycerin in 3\% peroxide, three times a week can often be helpful. Local corticosteroids have an important role in reducing inflammation. ${ }^{12}$
} 


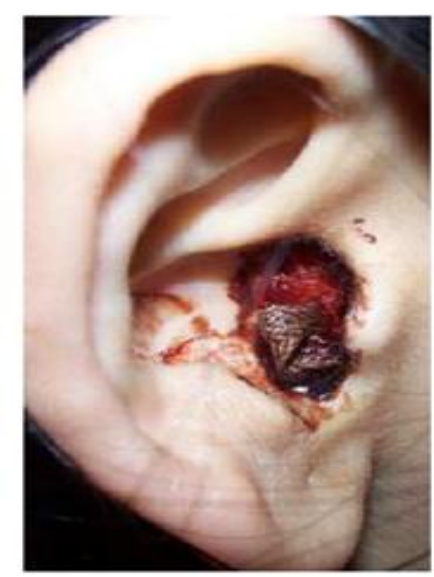

Figure 5. Keratosis is raised and treatment with betadin. ${ }^{11}$

According to Farrior (1990) after debris cleansing, recommend closing the MAE with a wet gauze of antibiotics and corticosteroids to reduce acute inflammation (figure 5). Patients who have experienced MAE bone erosion often require surgical intervention by tanning the tissues under the skin to remove the echo in the MAE wall, which is important to make MAE shaped like a funnel, so MAE cleansing is spontaneously more assured. ${ }^{11}$

\section{Complication}

Keratosis obturans is generally a harmless condition but can lead to serious complications. Keratosis obturans can cause extensive bone erosion including automastoidectomy but no intracranial complications are obtained. Plugs from squamous keratin squamous debris slowly become large can suppress the MAE bone in causing considerable reabsorption. After the appointment of a large enough plug, scooped out MAE will be obvious. Patients who have recurrent MAE plated keratin for five years will cause pressure on posterior MAE bone wall and mastoid wall to be resorbed which will result in automastoidectomy (figure 6).

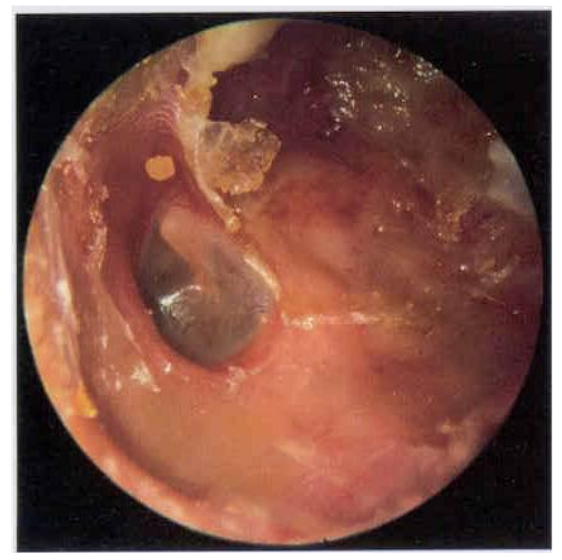

Figure 6. Secondary Automastoidectomy because of keratosis obturans. ${ }^{14}$

\section{Summary}

Keratosis obturans is a large accumulation of plaque from keratin desquamation distributed in the ear. The etiology of keratosis obturans remains unclear. Several hypotheses suggest keratosis obturans associated with eczema, seborrheic dermatitis and furunculosis. The keratosis obturans occurs due to epithelial abnormal migration of the MAE skin layer. The diagnosis of keratosis obturanceis made on the basis of anamnesis and clinical examination, while CT scan is performed to determine whether or not bone erosion is present. Anamnesis obtained severe ear pain, hearing loss bilateral conduction type, rare occurrence of otore. On otocopy examination keratin accumulation is seen, wider MAE and hyperemia, tympanic membrane is intact but thicker. On support examination of CT scan obtained erosion and widening of MAE. In the histopathologic examination, keratin blockage found in keratosis obturans looks like a geometric line inside the MAE that looks like an onion skin layer image.

This disease can usually be controlled by performing periodic ear canal cleansing once every one to three months to reduce debris accumulation. Ear dropping of mixtures of alcohol or glycerin in $3 \%$ peroxide, three times a week can often be helpful.

\section{Conflict of Interest}

The author stated there is no conflict of interest

\section{References}

1. Kroon DF, Strasnick B. Disease of the auricle, external auditory canal, and tympanic membrane. In: Glasscock ME, Gulya AJ, eds. Glasscock-Sambaugh Surgery of the Ear. $5^{\text {th }}$ ed. Ontario: BC Decker Inc; 2003. P.345-67

2. Lesser TH. Keratosis obturans and primary auditory canal cholesteatoma. In: Michael Gleeson, chief editor. Scott-Brown's Otolaryngology Head and Neck Surgery. 7th ed. Vol 3. London: Hodder Arnold; 2008. p. 3342-5.

3. Persaud RA, Hajioff D, Thevasagayam MS, Wareing MJ, Wright A. Keratosis obturans and external auditory canal cholesteatoma: How and why we should distinguish between these conditions. Clin Otol 2004;24:577-8. Available from: http://www.ncbi.nlm.nih.gov/pubmed/15533140. Accessed May 31,2014

4. Rogan JC, Leslie M, Tony W. Epithelial migration in keratosis obturans. American Journal of Otolaryngology 1996; 311-14. Available from: http://dx.doi.org/10.1016/S0196-0709. Accessed April 4, 2014

5. Piepergerdes MC, Kramer BM, Behnke EE. Keratosis obturans and external auditory canal cholesteatoma. Laryngoscope 1980;90:383-91. Available from: http://www.ncbi.nlm.nih.gov/pubmed/7359960. Accessed April 24, 2014

6. Loock JW. Benign necrotizing otitis externa. In: Michael Gleeson, chief editor. Scott-Brown's Otolaryngology Head and Neck Surgery. 7th ed. Vol 3. London: Hodder Arnold; 2008. p. 3334

7. Persaud R, Chatrath P, Cheesman A. Atypical keratosis obturans. J Laryngol Otol 2003;117:725-7. Available from: http://www.ncbi.nlm.nih.gov/pubmed/14561364. Accessed May 31,2014

8. Beatriz B, Amaya RF. Imaging diagnosis of benign lesions of the external auditory canal. Acta Otolaryngol Esc 2013;64:6-11. Available from: www.sciencedirect.com/science. Accessed April 4, 2014 
9. Saunders NC, Malhotra R, Biggs N, Fagan PA. Complications of keratosis obturans. J Laryngol Otol 2006;120:740-4. Available from: http://www.ncbi.nlm.nih.gov/pubmed/16848919. Accessed May 31, 2014

10. Negreiros J, Oliveira HF, Neves CA, Oliveira CA. External Auditory Canal Cholesteatoma . Int. Adv. Otol. 2009; 5:(3) 391393. Available from: www.scielo.br/scielo.php. Accessed April 18, 2014

11. Soucek S, Michaels L: Keratosis of the tympanic membrane and deep ecternal auditory canal. Eur Arch Otorhino laryngol 1993; 250: 140-2. Available from:

http://www.ncbi.nlm.nih.gov/pubmed/8357603. Accessed April 4, 2014

12. Tran LP, Grundfast KM, Selesnick SH. Benign lesions of the external auditory canal. Otolaryngol Clin North Am 1996;29(5): 807-825. Available from: http://www.ncbi.nlm.nih.gov/pmc/articles/. Accessed April 10, 2014

13. Glynn F, Keogh IJ, Burns H. Neglected keratosis obturans causing facial nerve palsy. J Laryngol Otol 2006;120:784-5. Available from: http://www.ncbi.nlm.nih.gov/pubmed/16939670. Accessed May 31, 2014

14. Michael H, Brian B, Heinz S, Bruce B. External auditory canal. In: Michael H, Brian B, Heinz S, Bruce B. Diagnostik handbook of otorhinolaryngology. London: Martin Duntz; 2002. p. 57-9 